\title{
BANKING EFFICIENCY AND EUROPEAN INTEGRATION. IMPLICATIONS OF THE BANKING REFORM IN ROMANIA
}

\author{
Jose L. Gallizo ${ }^{1}$ \\ Jordi Moreno ${ }^{2}$ \\ Ioana Iuliana Pop (Grigorescu)
}

\begin{abstract}
The aim of this study is to analyze the influence that the European integration process has had over the banking efficiency levels in those countries which have recently experienced more intensely the European integration process. For this purpose we have analyzed, using stochastic frontier models (SFA), applied to panel data, bank efficiency levels of a sample of 240 banks from 12 countries during the period 2000 to 2008. The results sustain the hypothesis that the European integration process has significantly improved the efficiency levels in these countries. However, the improvements haven't appeared simply by the accession to the EU, but have appeared during the process.

In order to illustrate the results, we have analyzed the banking system in Romania in the context of the European integration, a country which because of the delay in the initiation of the reforms, despite belonging to the EU, it hasn't still recorded the essential improvements in banking efficiency associated to this process that the other new members have already experienced.
\end{abstract}

Key words: banking efficiency, European integration, stochastic models, banking reform.

JEL Codes: C11, C73, F15, F36, G14, G21

\section{Introduction}

During the last two decades, the banking sectors of Central and Eastern European countries have suffered major modifications as a consequence of the European integration process that the majority of countries from this area have experienced, process that had two major milestones in the 2004 and 2007 enlargements.

To access to the EU the candidate countries had to adjust their national legislation to the Community standards, and banking regulations weren't one exception. At the same time, the possibility of entering into the Single capital market, generated by the belonging to EU represented for these countries a great opportunity reflected by the possibility of attracting large amounts of resources from the Western Europe, as well as, a big threat manifested it by the raise of competition in sectors not accustomed to compete.

We can see one example of this process in Romania, where the banking process reform started later than the majority of its neighbours (Romania has not introduced a dual banking system by 1990 , while other countries have introduced it since the 1980s, and Croatia and Macedonia since the 1960s). Moreover, Romania maintained a high participation of the State in this sector for several years.

In this paper we propose to analyze the influence that the European integration process has had on the banking performance in central and eastern European countries, referring especially to Romania.

\footnotetext{
${ }^{1}$ University of Lleida, Spain, e-mail: gallizo@aegern.udl.cat

${ }^{2}$ University of Lleida, Spain, e-mail:jmoreno@aegern.udl.cat

3 "1 Decembrie 1918" University of Alba Iulia, Romania, Faculty of Sciences, cotutoring Lleida University Spain, Faculty of Law and Economics, e-mail: ioanaiuliana69@yahoo.es
} 
As a starting point of our study, we assume the existence of significant differences in banking efficiency between countries according to the moment when they accessed to EU. Our hypothesis is that banks located in countries which have adhered to EU in 2004 have a higher banking efficiency than the ones located in countries which have adhered in 2007 or those who are still negotiating it. This hypothesis is based on the fact that these countries have reformed their banking system according to the Community requirements some years before the other analyzed countries, and also, due to the previous access to the Single capital market, factors that according to our point of view; contribute to improve the bank performance.

Some studies have analyzed the evolution of the banking efficiency over the integration process (Kasman and Yildirim, 2006; Mamatzakis et al., 2008, Rossi et al., 2004, etc.), but these works have focused on the previous years to the enlargements, in addition, there is no coincidence of results. For example, while Kasman and Yildirim (2006) have analyzed 8 new EU members during the period 1995-2002, without finding improves of banking efficiency over the period, Rossi et al. (2004), which also analyzed 8 new EU members during the same period, found some evidence of improvements for both cost and profit efficiencies. In more recent studies, which have analyzed more recent periods (Kosak, et al. 2009; Passiouras et al. 2009; among others), it seems to be more coincidence of results, showing that the European integration process have contributed to improve banking efficiency in the new EU members, especially in the costs side.

If we focus on Romania, there is a low number of researches regarding the efficiency of banks in Romania made with the help of frontier methods (Andrieş and Cocriş, 2009). For example, Asaftei and Kumbhakar (2008) estimate the cost efficiency of banks in Romania using a model that combines the stochastic frontier analysis and the cost function. They found that after the first major important regulation period (by the final of 90s), technical efficiency improved for all types of banks as a consequence of the policy changes introduced by the central bank. Furthermore, conclude that the evolution of the Romanian banking system post-2000 seems to indicate that the tightening of regulations by the central bank has generated other benefits besides reductions of technical inefficiency, as for example, the reduction of loans and interest listed as "doubtful" and "loss" in total loan portfolios.

Some studies (Fang et al., 2011 or Niţoi, 2009) also found a positive evolution of the banking sector in Romania in recent years; however, they show that in spite of the accession to the EU, Bulgaria and Romania have on average lower cost efficiency than the other countries which are still negotiation, as Croatia or Macedonia. Other studies (Fries and Taci, 2005 and Yildirim and Philippatos, 2007) analyzed banking efficiency in the Eastern Europe, and found that the country with the least efficient banks was Romania. Some studies indicate the ownership form as a reason of these results; for example, Niţoi (2009) found that most commercial banks in Romania are inefficient regarding the appropriate management costs, and that foreign banks are much more efficient than the local ones, which may be due to more efficient management techniques. In that sense, some authors as Stoica and Căpraru (2007) thought that a benefit from the massive presence of foreign (European) banks in the Romanian banking system would be probably visible after the EU integration.

However, other studies as Andrieş and Cocriş (2009), in addition to the ownership form, also point out other main factors influencing the level of bank efficiency like quality of assets, bank size, annual inflation rate, banking reform and interest rate liberalization level. Finally, the global economic financial crisis have also to be considerate as a determinant of banking efficiency, in that sense, Fang et al. (2011) show that for most countries of the region profit efficiency decreased significantly during the global financial crisis of the 2007-2009 period, albeit this drop varied by countries.

Finally we have analyzed the impact that the accession to EU has had over the banking efficiency comparing the levels obtained before and after their access to the EU. 


\section{Reform and banking privatization: the particular case of Romania}

Because of the economic and political situation in which the country was under a totalitarian regime, national and banking reforms started relatively late. Until 1990 the banking system in Romania was composed by the National Bank of Romania (BNR) and four national specialized banks: Romanian Bank of Foreign Trade, the Investment Bank, the Agricultural and Food Industry Bank and the Romanian Savings Bank (CEC).

At the end of 1990 the first reforms started in the sector. By this way, the BNR gave up at part of its functions, which were transferred to a new state commercial bank created for this purpose, the Commercial Romanian Bank (BCR). During the same year, the State allowed the entry of the private banks in the sector, passing from a single banking system to a two-tier banking system.

Specifically, in 1994 Romania adopted the Basel Accords regarding the capital adequacy requirements, while in 1995, the minimum capital requirements and the obligation of loss provisioning from credits were strengthened. During 1998 several laws were approved, and banking regulations began to be closer to the European standards, but it was not until 1999 when took place major structural evolutions in this sector, when the authorities adopted the first really important set of privatization measures. Although the Romanian authorities knew that privatization was the first really necessary step to improve the functioning of the banking system, the discussion about which was to be the role of the banks in the Romanian economy, the restructure cost of the banks with big office networks across the country, as well as the desire of the managers to stay in their position were the major obstacles for the privatisation process (Meyendorff and Thakor, 1997).

In turn, inside the process of banking reorganisation, some important banks had experienced heavy changes, for example Bancorex, the biggest commercial bank in Romania in 1998, was merged through absorption with BCR. At the same time, other big public banks had important problems, such as Agricola bank, which after some efforts by the government to restructure it, was privatized.

It is to be noticed that over the process of privatization and reform of the banking system, Romania had been for years the transitional country with the lowest presence of foreign ownership and the highest presence of the government ownership (Bonin, 2004). (See table 1).

Table no.1.

Evolution of banking assets according to the ownership (\% of total assets).

\begin{tabular}{|l|l|l|l|l|l|l|l|l|l|l|}
\hline Ownership form & $\mathbf{1 9 9 5}$ & $\mathbf{1 9 9 7}$ & $\mathbf{1 9 9 8}$ & $\mathbf{1 9 9 9}$ & $\mathbf{2 0 0 0}$ & $\mathbf{2 0 0 2}$ & $\mathbf{2 0 0 4}$ & $\mathbf{2 0 0 5}$ & $\mathbf{2 0 0 7}$ & $\mathbf{2 0 0 8}$ \\
\hline Foreign & 9 & 11.5 & 15.1 & 44 & 46.7 & 52.9 & 58.5 & 59.2 & 87.3 & 87.7 \\
\hline State & 84.3 & 80 & 75.3 & 50.3 & 50 & 43.6 & 7.5 & 6.5 & 5.7 & 5.6 \\
\hline Private national & 6.7 & 8.5 & 9.6 & 5.7 & 3.3 & 3.5 & 34 & 34.3 & 7 & 6.7 \\
\hline \multicolumn{2}{r}{ Source: EBRD and NBR. }
\end{tabular}

With the purpose of the EU adherence in January 2007, Romania had to make important efforts to adapt his legislation to the Community requirements. Today, the Romanian laws and banking regulations are in line with the European banking directives, something that as mentioned above, have improved the supervision banking system, promoting the implementation of a system of prior surveillance, and annual inspection by the BNR.

Between 2006 and 2007 (the year before the accession), the sector continued to attracting foreign investors, as can be noticed from the raise of foreign ownership, either by acquiring or by fusions with national banks.

Data

Balance sheet and income data are taken from the Bureau Van Dijk's BankScope database, which is monthly reviewed, and the last edition used in this study is from November 2009. 
Specifically, we have chosen all nowadays active commercial banks in the 12 countries that have experienced more intensely the European integration process in recent years (Bulgaria, Croatia, Czech republic, Estonia, Hungary, Latvia, Lithuania, Macedonia, Poland, Romania, Slovakia, and Slovenia), and for which there are available data for all necessary variables for the estimation of efficiency levels for at least one year between 2000 and 2008. Period selected due to the intensification of European integration process experienced during it.

In total, the data set consists of 240 banks, with 1,464 observations to estimate cost efficiency, and 1,450 observations to estimate profit efficiency. In Table 2, we can see the distribution of selected banks by country, and also, the number of active banks in each country in 2008.

Table no. 2 .

Distribution of banks by countries.

\begin{tabular}{|c|c|c|c|c|c|}
\hline Country & $\begin{array}{c}\text { Number of } \\
\text { commercial } \\
\text { banks in the } \\
\text { sample }\end{array}$ & $\begin{array}{c}\text { Number of } \\
\text { banks (all } \\
\text { types) in } \\
2008\end{array}$ & Country & $\begin{array}{c}\text { Number of } \\
\text { commercial } \\
\text { banks in } \\
\text { the sample }\end{array}$ & $\begin{array}{c}\text { Number of } \\
\text { banks (all } \\
\text { types) in } \\
2008\end{array}$ \\
\hline Bulgaria & 20 & 36 & Lithuania & 10 & 17 \\
\hline Croatia & 30 & 36 & Macedonia & 13 & 18 \\
\hline Czech Republic & 19 & 38 & Poland & 43 & 70 \\
\hline Estonia & 7 & 17 & Romania & 23 & 32 \\
\hline Hungary & 23 & 39 & Slovakia & 14 & 26 \\
\hline Latvia & 21 & 27 & Slovenia & 17 & 24 \\
\hline \multicolumn{6}{|c|}{ Total commercial banks in the sample $=\mathbf{2 4 0}$} \\
\hline
\end{tabular}

\section{Methodology.}

1. Stochastic frontier models.

In order to estimate the cost and profit efficiency we have used stochastic frontier models. We have used a Bayesian approach that let us to make exact inferences about the parameters of the model (Koop and Steel, 2003) without resorting to the use of asymptotic results of doubtful use in this context (an unbalanced panel with not very large number of series and a short sample size by series).

\subsection{The model.}

We have opted by the added value approach (Berger and Humphrey, 1992) and we have used three outputs: deposits (D), loans (L) and other earning assets (G), and two inputs prices: capital price (CP), (ratio of total operating expenses to fixed assets) and the fund price (FP), (ratio of financial expenses to total deposits). Our dependent variables are the total cost (C) in the cost efficiency and the profits before taxes (B) in the profit efficiency.

We have used a translog specification for the model with fixed effects for each country and year. So, if " $i$ " denotes the bank and " $t$ " the period, the equation of the model is given by:

$$
\begin{aligned}
\mathrm{y}_{\mathrm{it}}= & \alpha+\beta_{1} \mathrm{~d}_{\mathrm{it}}+\beta_{2} \ell_{\mathrm{it}}+\beta_{3} \mathrm{~g}_{\mathrm{it}}+\beta_{4} \mathrm{pc}_{\mathrm{it}}+\beta_{5} \mathrm{pf}_{\mathrm{it}}+\beta_{6} \mathrm{~d}_{\mathrm{it}}^{2}+\beta_{7} \mathrm{~d}_{\mathrm{it}} \ell_{\mathrm{it}}+\beta_{8} \mathrm{~d}_{\mathrm{it}} \mathrm{g}_{\mathrm{it}}+\beta_{9} \mathrm{~d}_{\mathrm{it}} \mathrm{pc}_{\mathrm{it}}+ \\
& +\beta_{10} \mathrm{~d}_{\mathrm{it}} \mathrm{pf}_{\mathrm{it}}+\beta_{11} \ell_{\mathrm{it}}^{2}+\beta_{12} \ell_{\mathrm{it}} \mathrm{g}_{\mathrm{it}}+\beta_{13} \ell_{\mathrm{it}} \mathrm{pc}_{\mathrm{it}}+\beta_{14} \ell_{\mathrm{it}} \mathrm{pf}_{\mathrm{it}}+\beta_{15} \mathrm{~g}_{\mathrm{it}}^{2}+\beta_{16} \mathrm{~g}_{\mathrm{it}} \mathrm{pc}_{\mathrm{it}}+\beta_{17} \mathrm{~g}_{\mathrm{it}} \mathrm{pf}_{\mathrm{it}}+ \\
& +\beta_{18} \mathrm{pc}_{\mathrm{it}}^{2}+\beta_{19} \mathrm{pc}_{\mathrm{it}} \mathrm{pf}_{\mathrm{it}}+\beta_{20} \mathrm{pf}_{\mathrm{it}}^{2}+\sum_{\mathrm{j}=2}^{12} \beta_{20+\mathrm{j}-1} \mathrm{IP}_{\mathrm{ij}}+\sum_{\mathrm{j}=2}^{9} \beta_{31+\mathrm{j}-1} \mathrm{IT}_{\mathrm{ij}}+\mathrm{u}_{\mathrm{it}}+\varepsilon_{\mathrm{it}}
\end{aligned}
$$

And if $\mathrm{y}_{\mathrm{it}}=\log \left(\mathrm{C}_{\mathrm{it}}\right)$, and

$$
\begin{aligned}
\mathrm{y}_{\mathrm{it}}= & \alpha+\beta_{1} \mathrm{~d}_{\mathrm{it}}+\beta_{2} \ell_{\mathrm{it}}+\beta_{3} \mathrm{~g}_{\mathrm{it}}+\beta_{4} \mathrm{pc}_{\mathrm{it}}+\beta_{5} \mathrm{pf}_{\mathrm{it}}+\beta_{6} \mathrm{~d}_{\mathrm{it}}^{2}+\beta_{7} \mathrm{~d}_{\mathrm{it}} \ell_{\mathrm{it}}+\beta_{8} \mathrm{~d}_{\mathrm{it}} \mathrm{g}_{\mathrm{it}}+\beta_{9} \mathrm{~d}_{\mathrm{it}} \mathrm{pc}_{\mathrm{it}}+ \\
& +\beta_{10} \mathrm{~d}_{\mathrm{it}} \mathrm{pf}_{\mathrm{it}}+\beta_{11} \ell_{\mathrm{it}}^{2}+\beta_{12} \ell_{\mathrm{it}} \mathrm{g}_{\mathrm{it}}+\beta_{13} \ell_{\mathrm{it}} \mathrm{pc}_{\mathrm{it}}+\beta_{14} \ell_{\mathrm{it}} \mathrm{pf}_{\mathrm{it}}+\beta_{15} \mathrm{~g}_{\mathrm{it}}^{2}+\beta_{16} \mathrm{~g}_{\mathrm{it}} \mathrm{pc}_{\mathrm{it}}+\beta_{17} \mathrm{~g}_{\mathrm{it}} \mathrm{pf}_{\mathrm{it}}+
\end{aligned}
$$




$$
+\beta_{18} \mathrm{pc}_{\mathrm{it}}^{2}+\beta_{19} \mathrm{pc}_{\mathrm{itt}} \mathrm{pf}_{\mathrm{it}}+\beta_{20} \mathrm{pf}_{\mathrm{it}}^{2}+\sum_{\mathrm{j}=2}^{12} \beta_{20+\mathrm{j}-1} \mathrm{IP}_{\mathrm{ij}}+\sum_{\mathrm{j}=2}^{9} \beta_{31+\mathrm{j}-1} \mathrm{IT}_{\mathrm{ij}}-\mathrm{u}_{\mathrm{it}}+\varepsilon_{\mathrm{it}}
$$

If $\mathrm{y}_{\mathrm{it}}=\log \left(\mathrm{B}_{\mathrm{it}}\right)$, where $\mathrm{d}_{\mathrm{it}}=\log \left(\mathrm{D}_{\mathrm{it}}\right) ; \ell_{\mathrm{it}}=\log \left(\mathrm{L}_{\mathrm{it}}\right) ; \mathrm{g}_{\mathrm{it}}=\log \left(\mathrm{G}_{\mathrm{it}}\right) ; \mathrm{pc}_{\mathrm{it}}=\log \left(\mathrm{PC}_{\mathrm{it}}\right) ; \mathrm{pf}_{\mathrm{it}}=$ $\log \left(\mathrm{PF}_{\mathrm{it}}\right)$; $\mathrm{IP}_{\mathrm{ij}}$ and $\mathrm{IT}_{\mathrm{ij}}$ are indicators of the $\mathrm{j}$-th country and the $\mathrm{j}$-th period, respectively; $\mathrm{u}_{\mathrm{it}}$ is the inefficiency term; $\varepsilon_{\text {it }} \sim \mathrm{N}\left(0, \sigma^{2}\right)$ is the error and $\mathrm{t} \in \mathrm{T}_{\mathrm{i}} \subseteq\{1, \ldots, \mathrm{T}\} ; \mathrm{i}=1, \ldots, \mathrm{N}$ where $\mathrm{T}_{\mathrm{i}}$ is the observation period of the $\mathrm{i}$-th bank and $\mathrm{N}$ is the number of analyzed banks.

\subsection{Estimation of the model.}

We estimate two types of stochastic efficiency models: one supposes that the efficiency term is distributed exponentially, and the other after a normal distribution.

The exponential model supposes that $\mathrm{u}_{\mathrm{it}} \sim \operatorname{Exp}\left(\lambda_{\mathrm{it}}\right) \quad \mathrm{cu} \lambda_{\mathrm{it}}=\gamma^{\prime} \mathrm{w}_{\mathrm{it}}$, while the normal distribution model supposes that $\mathrm{u}_{\mathrm{it}}=\mathrm{NT}_{(0, \infty)}\left(\gamma^{\prime} \mathrm{w}_{\mathrm{it}}, \sigma_{\mathrm{u}}^{2}\right), \mathrm{w}_{\mathrm{it}}=\left(\mathrm{w}_{\mathrm{it}}, \ldots, \mathrm{w}_{\mathrm{itk}}\right)^{\prime}$, being the bank's characteristics which explain the inefficiency and $\gamma=\left(\gamma_{1}, \ldots, \gamma_{\mathrm{k}}\right)^{\prime}$. The bank's efficiency is given in time by $r_{i t}=e^{-u_{i t}}$.

Considering the fact that the approach is Bayesian, it is necessary to specify from the very beginning the distribution of the model. In our case we have used the same distribution as Griffin and Steel (2007) considering:

$$
\begin{aligned}
& \alpha \sim \mathrm{N}\left(0,10^{6}\right) \\
& \beta=\left(\beta_{1}, \ldots, \beta_{39}\right)^{\prime} \sim \mathrm{N}_{39}\left(0,10^{6} \mathrm{I}_{39}\right) \\
& \tau=\frac{1}{\sigma^{2}} \sim \operatorname{Gamma}(0.001,0.001)
\end{aligned}
$$
exponential

$\gamma_{1} \sim \operatorname{Exp}\left(\lambda_{0}\right) \quad$ with $\quad \lambda_{0}=-\log \left(\mathrm{r}^{*}\right) \quad$ being $\quad \mathrm{r}^{*}=0.8 ; \quad \gamma_{\mathrm{i}} \sim \operatorname{Exp}(1) ; \mathrm{i}=2, \ldots, \mathrm{K}$ if the model is

$$
\gamma_{\mathrm{i}}=\psi_{\mathrm{i}} \sigma_{\mathrm{u}} ; \mathrm{i}=1, \ldots, \mathrm{K}
$$

Where $\psi_{1} \sim \mathrm{N}(0,1), \quad \mathrm{i}=1$ and $\psi_{\mathrm{i}} \sim \mathrm{N}(0,10) ; \mathrm{i}=2, \ldots, \mathrm{K}$

$\tau_{\mathrm{u}}=\frac{1}{\sigma_{\mathrm{u}}} \sim \operatorname{Exp}\left(5,5 \lambda_{0}\right)$ with $\lambda_{0}=-\log \left(\mathrm{r}^{*}\right)$ being $\mathrm{r}^{*}=0.8$ is the model is normal truncated.

The estimation of the parameters of the model was carried out from their posterior distribution calculated by using the Bayes theorem. Given that this distribution is not analytically tractable we use MCMC methods and, more concretely, the Gibbs sampling algorithm described in Griffin and Steel (2007). Using this algorithm we obtain a sample from the posterior distribution from which we calculated a point estimation and a 95\% Bayesian credibility interval of each parameter using the posterior median and 2.5 (Q2.5) and 97.5 (Q97.5) quartiles.

We used the DIC criterion of Spiegelhalter et al. (2002) to compare the goodness of fit of the exponential and the truncated normal model. Both the calculation of cost efficiency as for the profit efficiency, the truncated normal model showed a better goodness to the data.

The estimation of the parameters from the model was realised from the posterior distribution of its parameters calculated by applying Bayes theorem. Once estimated both models have been compared using DIC criterion of Spiegelhalter and others (2002) ${ }^{4}$. In both cases, the normal distributed model has shown a better shape reason for which the preceding results below presented are based on this model.

\footnotetext{
4 DIC criterion evaluates the adjust of the model with data, evaluating its predictive extra-sample behaviour and it is a combination between the matching the data, quantified by the term $\mathrm{D}^{-}$, and the parsimony degree of it, measured term PD, so that, as lower their value, the better the matching degree of the model to the data. For further details to be seen Koop and others (1997) and Griffin and Steel (2007).
} 


\section{Results}

To analyze how the European integration process has influenced the banking efficiency levels in the observed countries, we have estimated the cost and profit efficiency levels for 3 groups of banks according to the date of accession of the countries where they are located. The three groups are: banks from countries joined in 2004, banks from countries joined in 2007, and banks that are still negotiating with the EU. We can see the results for each group in Table 3 and in Figures 1 and 2.

Table no.3.

Influence on banking efficiency by the country according to the date access.

\begin{tabular}{|l|l|l|l|l|l|l|}
\multicolumn{1}{c}{} & \multicolumn{3}{c|}{ Cost efficiency } & \multicolumn{3}{c|}{ Profit efficiency } \\
\hline & $\mathrm{C} 2.5$ & Median & C97.5 & C2.5 & Median & C97.5 \\
\hline $\mathrm{E}[\mathrm{r} \mid$ joined in 2004] & 0.5462 & 0.6892 & 0.8341 & 0.8011 & 0.8874 & 0.9477 \\
\hline $\mathrm{E}[\mathrm{r} \mid$ joined in 2007] & 0.1326 & 0.2458 & 0.6161 & 0.5035 & 0.6069 & 0.6710 \\
\hline $\mathrm{E}[\mathrm{r} \mid$ still negotiating $]$ & 0.2116 & 0.3621 & 0.5020 & 0.5381 & 0.6437 & 0.7260 \\
\hline
\end{tabular}

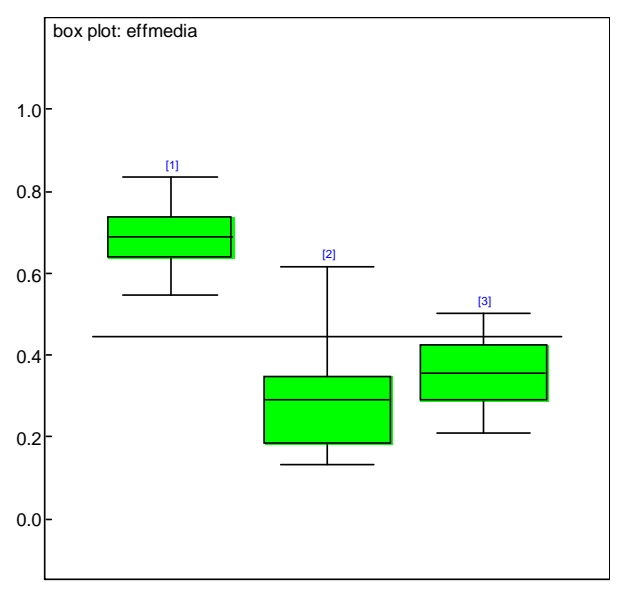

Figure 1. Boxplot of estimations for cost efficiency.

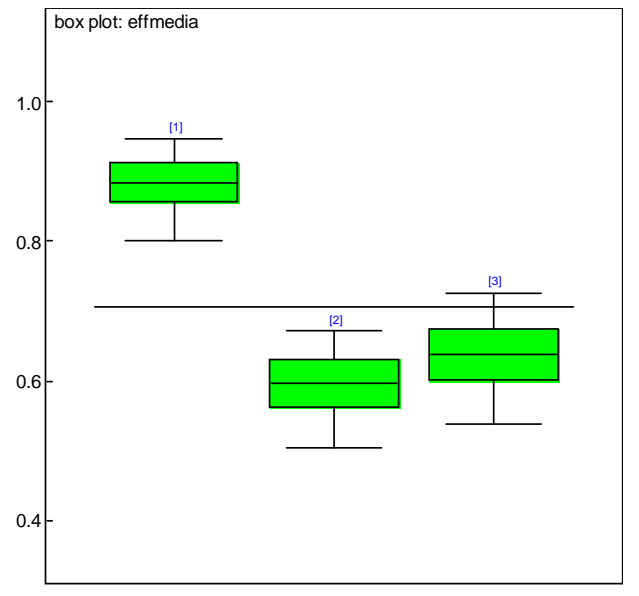

Figure 2. Boxplot of estimations for profit efficiency.

Results show that banks from countries that joined to EU in 2004 tend to be more efficient, both in cost $(68.92 \%)$ and profit $(88.74 \%)$ efficiency than banks located in other countries, which joined to EU in 2007 or which are still negotiating their accession, without being noticed significant differences between them.

These results confirm the hypothesis that the European integration process has contributed to improve the banking efficiency in those countries which have participated in this process, as shown by the fact that banks in countries which have joined earlier (in 2004), which have adapted their banking systems to the EU regulations and having access to the single capital market some years before, are the ones who present efficiency levels significantly higher than the rest of the banks included in the study.

If we focus on Romania and analyze Romanian banks joint with Bulgarian banks, and compare these banks with the other two groups, we notice, as we expected that banking efficiency, both for costs and profits, is lower in Romania and Bulgaria than those countries which have joined in 2004. Furthermore, results show that their efficiency levels are even lower than the levels of Croatia and Macedonia (these results are in line with Fang et al. (2011)), although differences between two groups are not statistically significant. This result suggests that belonging or not belonging to EU is not a decision factor to improve the efficiency levels in these countries; in contrast, having done the necessary banking reforms and restructuring seems to be a key factor. 
Considering this theory, the result it is not very surprising seeing the characteristics of the banking reform process experienced by the last two groups of banks. The reason is that while Bulgaria and specially Romania started the process of reform and bank privatisation relatively late, Croatia and Macedonia have a two-tier system banking since the middle of the 1960s.

As a proof of this double speed, we can see the percentage of participation in the sector by public and foreign ownership, from the first years of the process until today (see table 3). The banking ownership is one of the main indicators of this reform process in countries from Central and Eastern Europe, where as this process progressed, it reduced the participation of public ownership and raised the foreign presence in the sector. About this, there are authors who sustain the fact that the entry of foreign ownership has been the basis of the bank restructuring in these countries, due to foreign banks have entered in the region with a long time perspectives, offering stability, and improving the efficiency of the banking system. (Revoltella, 2006).

Table no.4.

Public and foreign ownership on the total banking assets by countries.

\begin{tabular}{|c|c|c|c|c|c|c|c|c|c|c|c|c|}
\hline \multicolumn{13}{|c|}{$\%$ of public ownership } \\
\hline & 1995 & 1998 & 1999 & 2000 & 2001 & 2002 & 2003 & 2004 & 2005 & 2006 & 2007 & 2008 \\
\hline Bulgaria & 81 & 56.4 & 50.5 & 19.8 & \begin{tabular}{|l|}
19.9 \\
\end{tabular} & 14.1 & 2.5 & 2.3 & 1.7 & 1.8 & 2.1 & 2 \\
\hline Croatia & 52 & 37.5 & 39.8 & 5.7 & 5 & 4 & 3.4 & $\overline{3.1}$ & 3.4 & 4.2 & 4.7 & 4.4 \\
\hline Macedonia & 0 & 1.4 & 1.2 & 1.2 & 1.3 & 2 & 1.8 & 1.9 & 1.6 & 1.6 & 1.4 & 1.2 \\
\hline Romania & 84.3 & 75.3 & 50.3 & 50 & 45.4 & 43.6 & 40.6 & $\overline{7.5}$ & 6.5 & 5.9 & 5.7 & 5.6 \\
\hline \multicolumn{13}{|c|}{$\%$ of foreign ownership } \\
\hline & 1995 & 1998 & 1999 & 2000 & 2001 & 2002 & 2003 & 2004 & 2005 & 2006 & 2007 & 2008 \\
\hline Bulgaria & 1 & 2 & 18 & 32.3 & 44.7 & 75.3 & 72.7 & 75.2 & 82.7 & 81.6 & 74.5 & 80.1 \\
\hline Croatia & 0.2 & 0.9 & 3 & 6.7 & 40.3 & 84.1 & 89.3 & 90.2 & 91 & 91.3 & 93 & 90.8 \\
\hline Macedonia & n.d. & 9.4 & 11.8 & 11.4 & 11.5 & 53.4 & 51.1 & $\overline{44}$ & 47 & 47.3 & 51.3 & 53.2 \\
\hline Romania & 9 & n.d. & 11.5 & 15.1 & 44 & 46.7 & 51.4 & $\overline{52.9}$ & 54.8 & 58.5 & 59.2 & 87.9 \\
\hline
\end{tabular}

In table 4 can be noticed that both Bulgaria and Romania have maintained a great presence of public ownership in this sector for several years, underlining the case of Romania, which until 2003 has maintained a presence of public sector in a percentage higher than $40 \%$. If we focus on foreign presence, we notice that until 2001 Romania (as well as in other countries) maintained quite low levels of this kind of ownership. Since big banks privatisation and with the entry of foreign investors, these levels have grown above 40\%. The foreign presence has been maintained until 2007 at levels below $60 \%$. These levels are relatively low if we compare them with the other new EU members, whose levels are above 80 and $90 \%$ for several years.

We think that this delay in the reform processes in Bulgaria and Romania justify their lower efficiency levels. Not in vain the persistence of a higher percentage of public ownership during the analyzed years, especially in the case of Romania, has prejudiced the levels of efficiency (several authors have found empiric evidence for the lower efficiency associated to this type of ownership, for example, Clark and Cull, 1999, La Porta et al, 2002, Bonin et al, 2005, etc).

Furthermore, the low presence of the foreign capital has not contributed to the improvement of these levels of efficiency. Several authors have noticed that the presence of foreign capital contributes to the improvement of competition. (Claessens et al, 2001), of stability (Buch et al, 2003) and also to foment the economic growth (Clayes and Haiz, 2006). Ultimately, studies regarding the relation between ownership and banking efficiency in the countries from Central and 
Eastern Europe have obtained higher efficiency levels for the foreign property (Weill, 2003; Bonin and others, 2005; Fries and Taci, 2005; Kasman and Yildirim, 2006; Vo Thi and Vencappa, 2007; etc.).

Moreover, in the case of Romania and Bulgaria, should be noticed the fact that as a result of the financial crises which started in 2007, these countries couldn't enjoy some inherent benefits to their condition of new EU members, such as attracting resources from the occidental banking systems, benefits that countries adhered in 2004 could enjoy. In addition, the crises has provoked in the central European countries an important process of taking back resources by the Western banks, fact that has limited the business possibilities and have generated an important instability in all these countries.

Seeing the tendency of growth in the efficiency levels as a result of the reform process associated to the European integration, we analyze the impact that the adherence has had on the banking efficiency levels. Table 5 presents the levels of efficiency, both in costs and profits, obtained by each bank, depending on if the observed period is before or after the date of accession. These results are graphically shown in Figures 3 and 4.

Table no. 5 .

Influence of date of accession on banking efficiency levels.

\begin{tabular}{|l|l|l|l|l|l|l|}
\cline { 2 - 7 } \multicolumn{2}{c|}{} & \multicolumn{3}{c|}{ Cost efficiency } & \multicolumn{3}{c|}{ Profit efficiency } \\
\hline & C2.5 & Median & C97.5 & C2.5 & Median & C97.5 \\
\hline$E\left[r_{t} \mid t \leq\right.$ date of access & 0.3743 & 0.4811 & 0.5700 & 0.6372 & 0.6845 & 0.7439 \\
\hline$E\left[r_{t} \mid t>\right.$ date of access & 0.3650 & 0.4904 & 0.6295 & 0.6221 & 0.6772 & 0.7407 \\
\hline
\end{tabular}

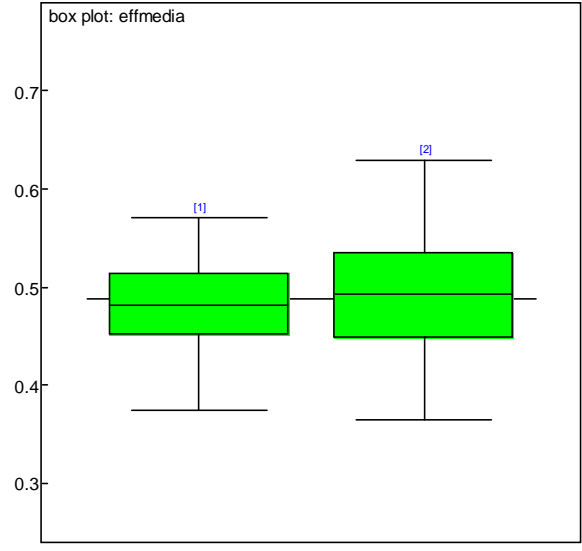

Figure 3. Boxplot of estimations for cost efficiency

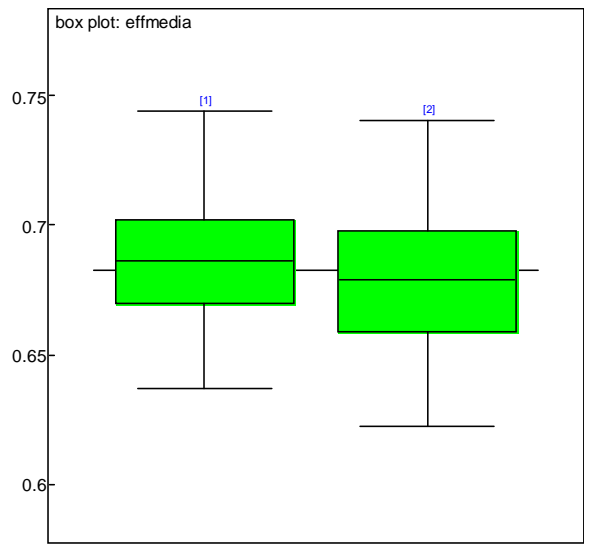

Figure 4. Boxplot of estimations for profit efficiency.

Results show a weak tendency to growth for cost efficiency and a reduction for profit efficiency, not seeing significant differences at $95 \%$ of trusting level.

One more time, this lack of significance indicates that the adherence has not meant an important change in the banking systems because of these sectors had been adapted to European regulations during the previous years, so when the adherence took place, these sectors had already experienced the most changes and the impact that this process implies. Moreover, the relations with the other member states in the single European market have already been intensified in the previous years too. 


\section{Conclusions}

Throughout the study, we have analyzed the influence of European integration process on banking efficiency in some Central and Eastern European countries. Results show that banks located in countries that joined to EU in 2004, which firstly adopted Community legislation and acceded before to the common capital market, are the ones which present higher levels of efficiency, both in costs and profits. This result sustains the hypothesis that the European integration process has contributed to the significant improvement of banking efficiency in these countries. Moreover, the lack of significance of the date of accession to the EU, leads us to the conclusion that these improvements in banking efficiency haven't produced spontaneously as a result of his accession, but have taken place throughout the process as they have adopted the Community standards and have intensified the relations with other member states.

About Romanian banking system, it is shown that the banking efficiency level is significantly lower than the ones obtained by the countries that adhered in 2004, but moreover, it is slightly lower than the ones obtained by Croatia and Macedonia, countries which are still negotiating with the EU. These findings support the previous conclusion, noting that the banking sector reform associated to the European integration process is more important that the simple accession to the EU. Thus, although other countries are still negotiating outside the EU, they started the banking reform process before Romania, who started this reform some years later, and it delayed the entry of foreign ownership in the sector and contributed to maintain the major role of public ownership, factors that undoubtedly have hindered the banking efficiency improvements during the analyzed years.

However, it is expected that when the international economic and financial situation improves, and Romania finish with remaining banking reforms, it will experience the banking efficiency improvements related with the European integration process, improvements widely observed in those countries who joined in 2004, who started the banking reform before, and furthermore, they enjoyed a more favourable economic context for development.

\section{Acknowledgement}

This paper has benefited from the financial support provided by Spanish Ministry of Science and Innovation, Research Project SEJ2007-67639/ECON

\section{References}

1. Andrieş A.M., Cocriş V. 2009. Comparative Analysis of the Efficiency of Romanian banks. In Poloucek S. and Stavarek D. (ed.) Structural and Regional Impacts of financial Crises, Silesian University, pp.3-28.

2. Asaftei G., Kumbhakar S. 2008. Regulation and efficiency in transition: the case of Romanian banks, Journal of Regulatory Economics, vol. 33(3), pp.253-282.

3. Berger A. N., Humphrey D.B., 1992. Measurement and efficiency issues in commercial banking" in Output Measurement in the Service Sectors (Ed.) Z. Griliches, The University of Chicago Press, Chicago, pp.245-479.

4. Bonin J.P., Hasan I., Wachtel P., 2005a. Bank performance, efficiency and ownership in transition countries, Journal of Banking and Finance, 29, pp.31-53.

5. Bonin J.P., Hasan I., Wachtel P. 2005b. Privatization matters: Bank efficiency in transition countries, Journal of Banking and Finance, 29, pp.2155-2178.

6. Bonin J.P., 2004. Banking in the Balkans: the structure of banking sectors in Southeast Europe, Economic Systems, Vol. 28, pp.141-153.

7. Buch C. et al., 2003. International Diversification in Bank Asset Portfolios, paper presented at the second Workshops of the ECB-CFS research network on Capital Markets and Financial Integration in Europe, Helsinki 11-12 March. 
8. Claessens S., Demirgüç-Kunt A., Huizinga H., 2001. How Does Foreign Entry Affect the Domestic Banking Market?, Journal of Banking and Finance, Vol. 25(5), pp. 891-911.

9. Clarke G., Cull R., 1999. Why privatize? The case of Argentina's public provincial banks, World Development, 27, pp.867-888.

10. Clayes S., Haiz C., 2006. Acquisition versus Greenfield, ECB Working Paper Series No.653.

11. Fang Y., Hasan I., Marton K., 2011. Bank efficiency in transition economies: Recent evidence from South-Eastern Europe, Bank of Finland Research Discussion Papers 5/2011.

12. Fries S., Taci A., 2005. Cost efficiency of banks in transition: Evidence from 289 banks in 15 post-communist countries, Journal of Banking and Finance, 29, pp. 2155-2178.

13. Griffin J.E., Steel M.F.J., 2007. Bayesian stochastic frontier analysis using WinBUGS, Journal of Prod. Analysis, 27, pp.163-176.

14. Kasman A., Yildirim C., 2006. Cost and profit efficiencies in transition banking: the case of new EU members, Applied Economics, 38(9), pp.1079-1090.

15. Kosak M., Zajc P., Zoric J. 2009. Bank efficiency differences in the new EU member states, Baltic Journal of Economics, 9(2), pp.67-90.

16. La Porta R., López-De-Silanes F., Shleifer A., 2002. Government Ownership of Banks, Journal of Finance, American Finance Association, vol. 57(1), pp. 265-301.

17. Mamatzakis E., Staikouras C., Koutsomanoli-Filippaki A., 2008. Bank efficiency in the new European Union member states: Is there convergence?, International Review of Financial Analysis 17, pp.1156-1172.

18. Meyendorff A., Thakor A.V., 1997. Romanian Financial System Reform, William Davidson Institute Working Paper No.100.

19. Niţoi M., 2009. Efficiency in the Romanian Banking System: An Application of Data Envelopment Analysis, Romanian Journal of Economics, vol. 29, 2(38), pp.162-176.

20. Pasiouras F., Tanna S., Zopounidis C., 2009. The impact of banking regulations on banks' cost and profit efficiency: Cross-country evidence, International Review of Financial Analysis, 18(5), pp.294-302.

21. Revoltella D., 2006. The EU banking sector integration, cross border M\&A and implications for the CEE., In Pekao Lecture The single Market, M\&A and European Competitiveness in a Globalized World, Krynica, September 6th, 2006.

22. Rossi S., Schwaiger M., Winkler G., 2004. Banking Efficiency in Central and Eastern Europe, Financial Stability Report 8, pp.77-91.

23. Spiegelhalter D.J., Best. N.G., Carlin B.P., van de Linde, A., 2002. Bayesian measures of model complexity and fit (with discussion), Journal of the Statistical Royal Society B, 64, pp.583-640.

24. Stoica, O., Căpraru B., 2007. The effects of the competition in the Romanian banking system, Analele Ştiintifice ale Universităţii Alexandru Ioan Cuza Iaşi. Vol.54 (November), pp.67-72.

25. Vo Thi N., Vencappa D., 2008. Does the Entry Mode of Foreign Banks Matter for Bank Efficiency? Evidence from Czech Republic, Hungary and Poland, William Davidson Institute Working Paper No. 925.

26. Weill L., 2008. Banking efficiency in transition economies, The economics of Transition, EBRD. Vol. 11(3), pp.569-592.

27. Yildirim S.H., Philippatos G., 2007. Efficiency of Banks: Recent Evidence from the Transition Economies of Europe, 1993-2000, The European Journal of Finance, 13(2), pp.123-143. 